\title{
Expression of enzyme associated with steroid hormone synthesis and local production of steroid hormone in endometrial carcinoma cells
}

\author{
T Sugawara, E Nomura ${ }^{1}$ and S Fujimoto ${ }^{1}$ \\ Department of Biochemistry, Graduate School of Medicine, Hokkaido University, Kita-ku, Kita 15, Nishi 7, Sapporo 060-8638, Japan \\ ${ }^{1}$ Department of Obstetrics and Gynecology, Graduate School of Medicine, Hokkaido University, Kita-ku, Kita 15, Nishi 7, Sapporo 060-8638, Japan \\ (Requests for offprints should be addressed to T Sugawara; Email: terusuga@med.hokudai.ac.jp)
}

\begin{abstract}
Endometrial carcinoma is a common malignancy of the genital tract. In the present study, we examined the expression of human steroidogenic acute regulatory (StAR) protein, P450 side-chain cleavage enzyme (P450 scc), 17 $\alpha$-hydroxylase/17,20-desmolase (P45017 $\alpha$ ) and aromatase ( $\mathrm{P} 450$ arom) in endometrial carcinoma cells to clarify the ability of these cells to produce steroid hormones. The results of RT-PCR analysis showed that StAR, P450 scc and P45017 $\alpha$ genes were expressed in endometrial carcinoma cells. To examine the protein expression of StAR and P450 scc, we performed Western blotting using extracts from carcinoma cells. StAR protein and P450 scc were detected in both HHUA and HOUA-1 cells. The production of pregnenolone in
\end{abstract}

HHUA cells increased $2 \cdot 4$-fold with transfection of a StAR expression vector and $4 \cdot 3$-fold with transfection of an F2 side-chain cleavage system. The RT-PCR product of $3 \beta$-hydroxysteroid dehydrogenase was present in endometrial carcinoma cells. In endometrial carcinoma cells, the production of progesterone also increased with over-expression of StAR and the F2 system. Results of steroid metabolic assays showed that endometrial carcinoma cells produced not only $17 \alpha$-hydroxyprogesterone but also androstenedione. Endometrial carcinoma cells express enzymes that are associated with the production of steroid hormones. Locally produced steroid hormones may have effects on tumor proliferation and tumorigenesis.

Journal of Endocrinology (2004) 180, 135-144

\section{Introduction}

Endometrial carcinoma arises from the endometrium, which is affected by steroid hormones. Endometrial carcinoma cells are also affected by steroid hormones. Prolonged estrogen stimulation, such as that caused by nulliparity, late menopause, obesity and diabetes mellitus, has been identified as a risk factor for the development of endometrial carcinoma (Kelsey et al. 1982). Progesterone, which has differential actions on the normal endometrium, is effective for the treatment of endometrial carcinoma (Kelley \& Baker 1961). Selection of progesterone treatment depends on the expression of estrogen and progesterone receptors in cancer cells. However, there is some controversy regarding the choice of progesterone treatment because metastasis of early-stage carcinoma can occur in some cases in which progesterone treatment has been effective due to qualitative or quantitative changes in estrogen receptors (ER) or progesterone receptors $(\mathrm{PR})$ in both ovulatory and post-menopausal women (Runowicz et al. 1990). There is no relationship between levels of circulating steroid hormones and the expression of ER and PR in endometrial carcinoma (Spona et al. 1979).

The first step in the biosynthesis of steroid hormones is the conversion of cholesterol into pregnenolone. The rate-limiting process is the transport of cholesterol from the outer mitochondrial membrane to the inner membrane, where $\mathrm{P} 450$ side-chain cleavage enzyme (P450 scc) and its associated electron transport proteins reside. Steroidogenic acute regulatory (StAR) protein promotes the intramitochondrial transport of cholesterol and controls the rate-limiting step in steroidogenic tissues. StAR protein is synthesized as a $37 \mathrm{kDa}$ precursor that is imported into mitochondria, where cleavage of the mitochondria targeting sequence occurs to yield a $30 \mathrm{kDa}$ StAR protein (Strauss et al. 1999). The StAR gene is mutated in subjects with congenital lipoid adrenal hyperplasia, resulting in marked impairment of adrenal gonadal steroid synthesis (Lin et al. 1995). StAR expression is restricted to steroidproducing cells of the adrenal gland, testis and ovary (Sugawara et al. 1995).

Steroid hormones are produced from cholesterol in tissues other than the adrenal gland and gonads. It has 
recently been demonstrated that the central nervous system, vascular wall and heart synthesize the steroid hormones pregnenolone, progesterone, dehydroepiandrosterone, corticosterone and aldosterone (Le Goascogne et al. 1987, Takeda et al. 1996, KayesWandover \& White 2000). Although enzymes necessary for the synthesis of steroid hormones have been found in these tissues by RT-PCR analysis, the levels of expression of steroidogenic enzyme genes were lower than those in the adrenal gland (Kayes-Wandover \& White 2000). Steroid hormones synthesized in local tissues are thought to be biologically active with an autocrine or paracrine action (Le Goascogne et al. 1987, Takeda et al. 1996, Kayes-Wandover \& White 2000).

It is well known that there is a close relationship between the prognosis of patients with endometrial carcinoma and the degree of differentiation of carcinoma cells. It has been reported that there is a correlation between the expression of ER and $\mathrm{PR}$ and the degree of tumor differentiation (McCarty et al. 1979). HHUA cells, which are highly differentiated endometrial carcinoma cells, express both ER and PR whereas HOUA cells, which are undifferentiated endometrial carcinoma cells, express neither ER nor PR (Ishiwata et al. 1984). In the present study, we examined the expression of StAR protein and other P450 enzymes associated with steroid hormone synthesis in HHUA and HOUA-1 cells to clarify the ability of endometrial carcinoma cells to produce steroid hormones.

\section{Materials and Methods}

\section{Plasmid constructs}

Human StAR cDNA was cloned into the pSV-SPORT 1 expression vector plasmid by inserting the SalI/NotI resting cutting sites as previously described (Sugawara et al. 1995). Expression vectors for bovine adrenodoxin (pCDADX) were kindly provided by Michael Waterman (Vanderbilt University, Nashville, TN, USA). The human P450 scc-adrenodoxin reductase-adrenodoxin fusion enzymes of the cytochrome P450 scc system, called the F2 system, were kindly provided by Dr Walter L Miller of the University of California, San Francisco, CA, USA.

\section{Cell culture}

Human HHUA highly differentiated endometrial carcinoma cells, HOUA-1 undifferentiated endometrial carcinoma cells and Hep G2 liver carcinoma cells were obtained from the RIKEN Cell Bank (Tsukuba, Japan). Human adrenocortical carcinoma H295R cells were a gift from Dr Mitsuhiro Okamoto, Osaka University Medical School (Osaka, Japan). The cells were grown in $35 \mathrm{~mm}$ plastic dishes. HHUA, HOUA-1 and Hep G2 cells were cultured in Dulbecco's modified Eagle's medium (DMEM) supplemented with 10\% fetal calf serum and $50 \mu \mathrm{g} / \mathrm{ml}$ gentamycin. H295R cells were grown in DMEM/F12 containing 2\% ULTROSER G (BioSepra, Cergy-Pontoise, France) and 1\% ITS Premix (Becton Dickinson and Co, Franklin Lakes, NJ, USA).

\section{Transfection and steroid hormone assays}

HHUA, HOUA-1 and Hep G2 cells were cultured at $40 \%-60 \%$ confluence in a medium with serum. Onetenth of a milliliter of serum-free medium contained F2, pSport StAR or pCDADX with $3 \mu$ Fugene 6 (Roche Molecular Biochemicals, Mannheim, Germany) per $1 \mu \mathrm{g}$ DNA. Dishes were treated with $20 \mu \mathrm{M}$ trilostane (provided by Mochida Pharmaceutical Co Ltd, Tokyo, Japan) at $6 \mathrm{~h}$ after transfection to inhibit the enzyme activity of

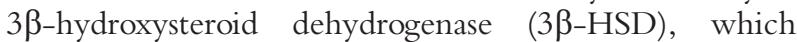
transforms pregnenolone to progesterone (Potts et al. 1978). In some dishes, 22R-hydroxycholesterol $(5 \mu \mathrm{g} / \mathrm{ml})$, which is a more soluble pregnenolone precursor and is an intermediate in the cholesterol side-chain cleavage reaction, was added to the culture medium. This hydroxysterol bypasses the translocation mechanism of cholesterol by which cholesterol is transported from the outer mitochondrial membrane to the inner membrane (Toaff et al. 1982). The culture medium was collected $48 \mathrm{~h}$ after transfection for RIA of pregnenolone as described previously (Sugawara et al. 1995). Progesterone was measured using a Progesterone Correlate-EIA Kit (Assay Designs Inc, Ann Arbor, MI, USA). Pregnenolone assays were performed using endometrial carcinoma cells without co-transfection of expression plasmids to evaluate pregnenolone accumulation in the medium. The culture medium with $20 \mu \mathrm{M}$ trilostane was collected at various times after medium change. To evaluate pregnenolone and progesterone accumulation in the culture medium, trilostane was not added to the culture medium. Pregnenolone and progesterone were assayed in culture media collected at various times after medium change.

\section{Reverse transcription-polymerase chain reaction (RT-PCR)}

Total RNA was isolated from HHUA, HOUA, Hep G2 and H295R cells. Complementary DNA synthesis was carried out at $37^{\circ} \mathrm{C}$ for $60 \mathrm{~min}$ using $150 \mathrm{pmol}$ oligo dT as a primer, $1 \mu \mathrm{g}$ total RNA and 200 units SUPERSCRIPT II RNase H (Life Technologies Inc/BRL, Washington, DC, USA). Twenty microliters volume of reaction mixture for reverse transcriptase contained $50 \mathrm{mM}$ Tris- $\mathrm{HCl}$ (pH 8.3), $75 \mathrm{mM} \mathrm{KCl,} 3 \mathrm{mM} \mathrm{MgCl}_{2}, 20 \mathrm{mM}$ dithiothreitol and $0.5 \mathrm{mM}$ each of dATP, dCTP, dGTP and dTTP. Next, PCR reactions were carried out with $1 \mu \mathrm{l}$ reverse transcription (RT) reaction product using the following primers. We designed oligonucleotide primers for amplification of StAR (Sugawara et al. 1995) 
(sense, 5'-GCAGCAGCAGCGGCGGCAGCAG-3'; antisense, 5'-ATGAGCGTGTGTACCAGTG-3'), and P450 scc (Matteson et al. 1986a) (sense, 5'-ATGC TGGAGGAAGTAGTG-3'; antisense, 5'-TCCTGCC AGCATCTCTGT-3'), P45017 $\alpha$-hydroxylase/17,20desmolase (P45017 $\alpha$ ) (Matteson et al. 1986b) (sense, 5'-CATGCTGGACACACTGATGC-3'; antisense, 5'CCTCCAGGCCTGGCGCACCT-3'), and P450 aromatase (P450 arom) (Simpson et al. 1987) (sense, 5'-CGGCCTTGTTCGTATGGTCA-3'; antisense, 5'GTCTCATCTGGGTGCAAGGA-3'). Fifty microliters of the PCR reaction mixture contained $10 \mathrm{mM}$ Tris- $\mathrm{HCl}$ (pH 8.3), $50 \mathrm{mM} \mathrm{KCl,} 1.5 \mathrm{mM} \mathrm{MgCl}_{2}, 0.2 \mathrm{mM}$ dNTPs and $10 \mathrm{pmol}$ each of the primers. The reaction was subjected to 35 cycles of denaturing at $94{ }^{\circ} \mathrm{C}$ for $45 \mathrm{~s}$, annealing at $55^{\circ} \mathrm{C}$ (P450 arom and StAR) for $45 \mathrm{~s}$ and extension at $72{ }^{\circ} \mathrm{C}$ for $1 \mathrm{~min}$ or subjected to 40 cycles of denaturing at $94{ }^{\circ} \mathrm{C}$ for $45 \mathrm{~s}$, annealing at $57^{\circ} \mathrm{C}$ for $45 \mathrm{~s}$ and extension at $72{ }^{\circ} \mathrm{C}$ for $1 \mathrm{~min}$ (P450 scc and P45017 $\alpha$ ). There are two $3 \beta$-HSD isoenzymes in humans, which are chronologically designated type I and type II. PCR was performed using the following primers for $3 \beta$-HSD (Lorence et al. 1990, Rheaume et al. 1991): sense, 5'TGGAGCTGCCTTGTGACAGGA-3'; antisense, 5'CATCTGGAATCAAGGCGGAG-3'. The reaction was subjected to 35 cycles of denaturing at $94{ }^{\circ} \mathrm{C}$ for $30 \mathrm{~s}$, annealing at $60{ }^{\circ} \mathrm{C}$ for $30 \mathrm{~s}$ and extension at $72{ }^{\circ} \mathrm{C}$ for $1 \mathrm{~min}$. After the reaction, primers were removed using a QIAquick PCR Purification Kit (QIAGEN, Hilden, Germany). Then, the PCR products $(1 / 30)$ were subjected to 20 cycles under the same conditions using the following set of primers: sense, 5'-CAAGACCAA GCTGACAGTGC-3'; antisense, 5'-TATCATAGCT TTGGTGAGGCG-3'. RT-PCR products were then digested with HpaI to discriminate between type I and type II $3 \beta-H S D$.

\section{Western blotting}

Cells collected into homogenization buffer consisting of $0 \cdot 25 \mathrm{M}$ sucrose, $10 \mathrm{mM}$ Tris- $\mathrm{HCl}, \mathrm{pH} \mathrm{7 \cdot 4}$, and $10 \mathrm{mM}$ EDTA were sonicated for $5 \mathrm{~s}$. Disrupted cells were centrifuged at $600 \mathrm{~g}$ for $15 \mathrm{~min}$, and the supernatant was used for Western blot analysis. Protein extracts $(10 \mu \mathrm{g})$ were electrophoresed in $12.5 \%$ polyacrylamide gel in the presence of $2 \%$ SDS and then transferred onto a nitrocellulose membrane or polyvinylidene difluoride (PVDF) membranes for immunodetection with rabbit anti-StAR serum or anti-P450 scc serum. Dr Jerome F Strauss III of the University of Pennsylvania, Philadelphia, USA generously provided human anti-StAR serum. Human anti-P450 scc was a gift from Dr Toshihiro Tajima of Hokkaido University School of Medicine, Sapporo, Japan. The signal was detected by chemiluminescence using ECL or ECL-Plus Western blotting detection reagents (Amersham Pharmacia Biotech, Uppsala, Sweden).

Steroid metabolism assays

Steroid metabolism assays were performed by the method of Nelson and McAllister with slight modification (Nelson et al. 1999). Cell cultures were grown until subconfluence in $100 \mathrm{~mm}$ plastic dishes and were washed twice with DMEM/F12 serum-free medium. The medium was then replaced by DMEM/F12 with 2\% ULTROSER G and $1 \%$ ITS Premix containing tritiated pregnenolone $\left(\left[{ }^{3} \mathrm{H}\right]-\right.$ P5) $(2 \cdot 0 \mu \mathrm{M})$. The medium was collected after 12, 24, 36 and $48 \mathrm{~h}$ of culture. Steroids were extracted from the medium with four volumes of dichloromethane. The residue was dissolved in methanol and subjected to reverse-phase HPLC using a TSKgel ODS-120T column of $4.6 \mathrm{~mm}$ internal diameter $\times 15 \mathrm{~cm}$ in length and with a pore size of $5 \mu \mathrm{m}$ in diameter (Toso, Tokyo, Japan). The HPLC system consisted of a Shimadzu LV-9A pump and an SPD-6A UV detector (Shimadzu Corporation, Kyoto, Japan). The gradient solvent delivery system consisted of 1:1 acetonitrile/methanol (A/M) and water (45:55) for $2 \mathrm{~min}$ followed by a $2-\mathrm{min}$ linear gradient to $60 \% \mathrm{~A} / \mathrm{M}$ for $2 \mathrm{~min}$, a $21-\mathrm{min}$ linear gradient to $68 \% \mathrm{~A} / \mathrm{M}$ for $1 \mathrm{~min}$ and then a 3-min linear gradient to 100\% A/M. Radioactivity was measured by a liquid scintillation counter. The retention times of authentic steroid standards were established for the nonreduced and reduced steroids at 240 and $210 \mathrm{~nm}$ respectively.

\section{Data analysis}

Values are presented as means \pm S.E. Significance between experimental groups was determined by Student's unpaired t-test. $P<0.05$ was taken as the level of significance.

\section{Results}

Expression of steroidogenesis-associated enzymes in human endometrial carcinoma cells

RT-PCR analysis was performed to examine the gene expression of enzymes associated with synthesis of steroid hormones, including human StAR protein, P450 scc, $\mathrm{P} 45017 \alpha$ (P450c17) and $\mathrm{P} 450$ arom in the two human endometrial carcinoma cell lines, HHUA and HOUA-1, and in the two additional cell lines, Hep G2 and H295R cells. Hep G2 human liver carcinoma cells are nonsteroidogenic cells, and H295R human adrenocortical carcinoma cells, which were used as a positive control for RT-PCR, are steroidogenic cells (Fig. 1). StAR RTPCR products (975 bp) were present in both HHUA and HOUA-1 cells. StAR PCR products were also found to 


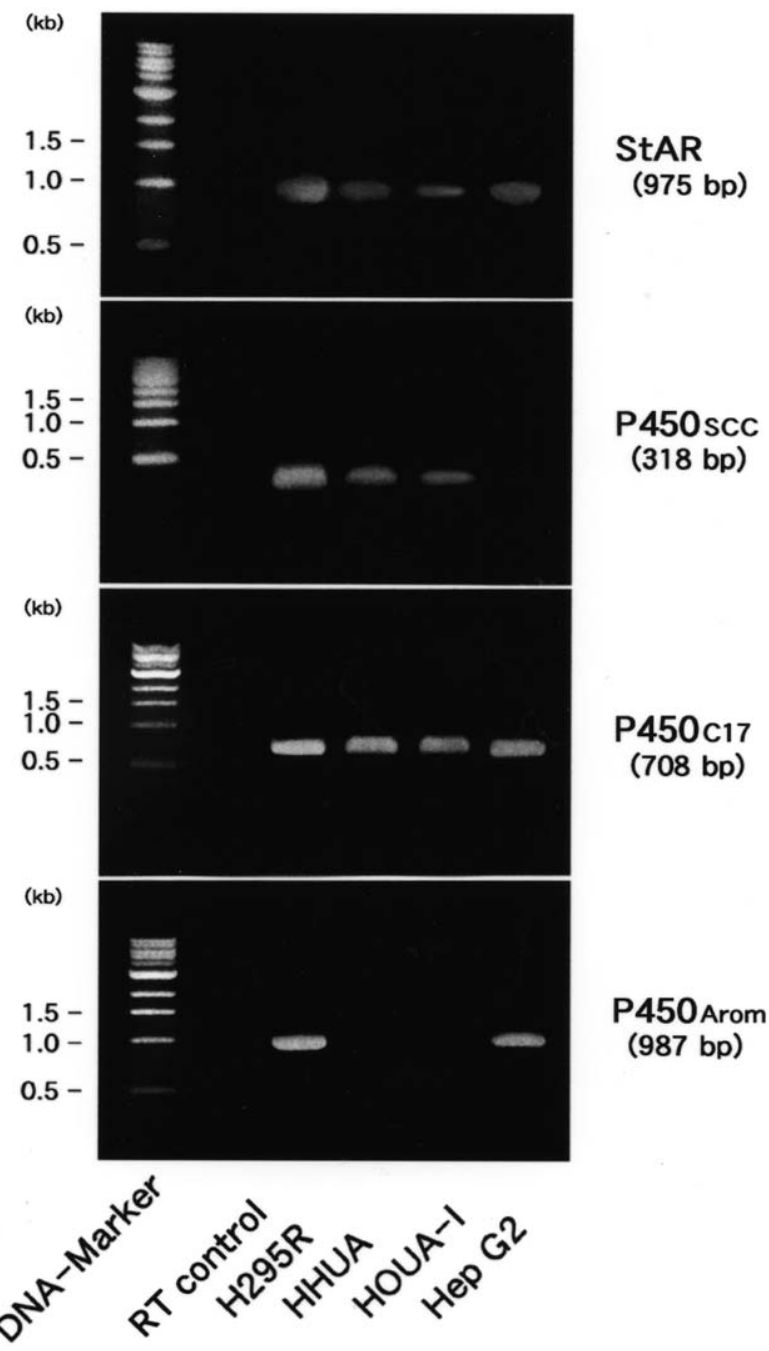

Figure 1 Gene expression of enzymes associated with steroid hormones in carcinoma cells. RT-PCR was performed using mRNA extracted from HHUA cells (highly differentiated endometrial carcinoma cells), from HOUA-1 cells (poorly differentiated endometrial carcinoma cells), from H295R cells (human adrenal adenocarcinoma cells), and from Hep G2 cells (human liver adenocarcinoma cells). The sizes of the PCR products were 975 bp (StAR), 318 bp (P450 scC), 708 bp (P45017 $\alpha$; P450c17) and $987 \mathrm{bp}$ (P450 arom). A positive control was amplified using mRNA from H295R cells. A negative control was amplified without $\mathrm{RT}$ reaction mixture.

be present in Hep G2 liver carcinoma cells. P450 scc RT-PCR products (318 bp) were present in both HHUA and HOUA-1 cells but not in Hep G2 cells. P45017a RT-PCR products (708 bp) were present in HHUA, HOUA-1, and Hep G2 cells. P450 arom PCR products (987 bp) were not present in HHUA or HOUA-1 cells. Thus, the steroidogenesis-associated genes StAR, P450 scc and $\mathrm{P} 45017 \alpha$, but not $\mathrm{P} 450$ arom, were expressed in endometrial carcinoma cells. Endometrial carcinoma cells
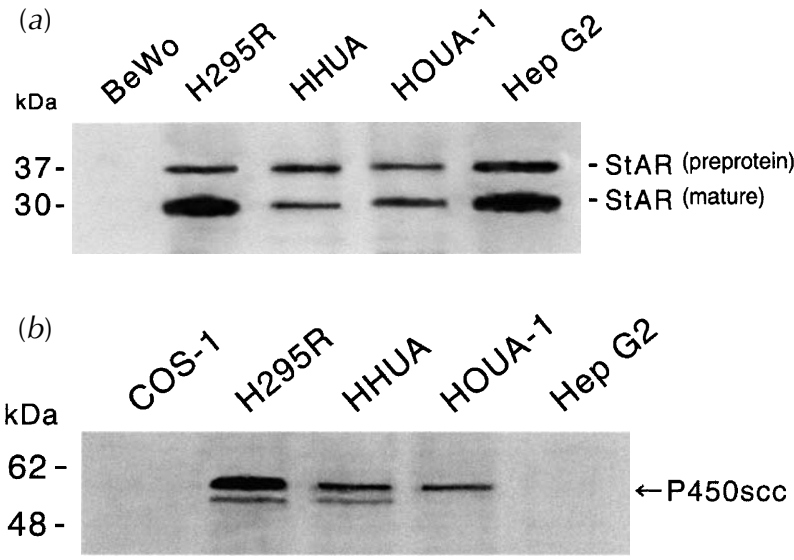

Figure 2 Expression of StAR and P450 scc proteins in endometrial carcinoma cells. Western blotting was performed using HHUA, HOUA-1, Hep G2 and H295R cells. Mitochondrial protein $(15 \mu \mathrm{g})$ was electrophoresed on $12 \%$ polyacrylamide gel containing $0 \cdot 1 \%$ SDS and then immunoblotted onto a PVDF membrane with (a) StAR or (b) P450 scc antiserum. BeWo cell extract was used as a negative control for StAR protein. COS- 1 cell extract was used as a negative control for P450 scc protein. Immunodetection was carried out using an ECL-Plus detection kit.

thus contain mRNA coding for enzymes involved in the synthesis of progesterone and androgens but not estrogens.

Expression of StAR and P450 scc proteins in endometrial carcinoma cells

StAR and P450 scc gene expression was detected in endometrial carcinoma cells by using RT-PCR. To confirm the protein expression of StAR and P450 scc in endometrial carcinoma cells, we performed Western blotting using mitochondrial extracts from cells. StAR protein was found to be present in HHUA cells and HOUA-1 cells (Fig. 2A). P450 scc protein was detected in HHUA and HOUA-1 cells (Fig. 2B). Although StAR protein was present, P450 scc protein was not present in Hep G2 cells.

\section{Production of pregnenolone in carcinoma cells}

To determine whether endometrial carcinoma cells synthesize steroid hormones and release steroid hormones into the culture medium, we measured the amount of pregnenolone in a culture medium with over-expression of StAR or the F2 P450 scc system. In HHUA cells, the production of pregnenolone was increased 2.4-fold with the StAR expression vector relative to that of mock transfection. With the F2 system, the production of pregnenolone increased 4.3-fold. With the ADX expression vector, the production of pregnenolone increased $2 \cdot 9$-fold. When 22R-hydroxycholesterol was added to the culture medium, the production of pregnenolone increased with the F2, StAR or ADX expression vectors. When 22R-hydroxycholesterol was added to the culture 
medium, the production of pregnenolone was increased much more with the F2 system (Fig. 3A). The results suggest that the expression level of $\mathrm{P} 450 \mathrm{scc}$ was increased compared with the expression levels of other factors. In HOUA-1 cells, the production of pregnenolone did not increase with the F2, StAR, or ADX expression vector (Fig. 3B). Transfection with F2, StAR or ADX did not increase pregnenolone production in Hep G2 cells. When 22R-hydroxycholesterol was added to the culture medium, the production of pregnenolone was increased with the F2 system in Hep G2 cells (Fig. 3C). Protein extracts from transfected cells were analyzed using Western blotting. StAR and P450 scc system proteins were detected in transfected cells (Fig. 3D). To evaluate pregnenolone accumulation in endometrial carcinoma cells, we assayed pregnenolone in the medium at various culture times. Pregnenolone accumulation was observed with timedependent increases in both endometrial carcinoma cell lines. The level of pregnenolone production in HHUA cells had increased after $12 \mathrm{~h}$ of culture. Accumulation of pregnenolone in HOUA-1 cells was observed at $48 \mathrm{~h}$ (Fig. 3E).

\section{$3 \beta-H S D$ expression in endometrial carcinoma cells}

We examined the gene expression of $3 \beta-H S D$ to determine the ability of endometrial carcinoma cells to metabolize pregnenolone to progesterone. RT-PCR was performed using mRNA extracted from HHUA, HOUA-1, Hep G2 and H295R cells. PCR products (644 bp) obtained by amplifying $3 \beta-H S D$ transcripts were present in HHUA, HOUA-1, Hep G2 and H295R cells (Fig. 4A). The primers selected for the analysis do not discriminate between type I and type II $3 \beta-$ HSD transcripts. RT-PCR products were digested with HpaI, which selectively cut type I $3 \beta-H S D$ PCR products, because the HpaI restriction site is not present in type II $3 \beta-H S D$ PCR products. HpaI digestion of RT-PCR products from the type I $3 \beta-H S D$ gene resulted in the production of two fragments, a 508-bp fragment and a 136-bp fragment (Fig. 4B). H295R cells have type I and type II 3 $\beta$-HSD gene expression (Lorence et al. 1990, Rheaume et al. 1992). Digestion of PCR products from H295R produced fragments of $644 \mathrm{bp}, 588 \mathrm{bp}$ and $136 \mathrm{bp}$. Digestion of PCR products from HHUA cells and Hep G2 cells produced fragments of $508 \mathrm{bp}$ and $136 \mathrm{bp}$. PCR products of HOUA-1 cells were not digested with HpaI (Fig. 4C). These results indicated that type I $3 \beta-H S D$ was present in HHUA cells and that type II $3 \beta$-HSD was present in HOUA-1 cells. $3 \beta$-HSD genes were expressed in endometrial carcinoma cells.

\section{Production of progesterone in endometrial carcinoma cells}

To further investigate the metabolism of pregnenolone, we examined the production of progesterone in endo- metrial carcinoma cells without trilostane in the culture medium. Progesterone production was significantly increased with the F2 system transfected into HHUA cells with or without the addition of 22R-hydroxycholesterol to the culture medium. Progesterone production was not increased when the StAR expression vector, $\mathrm{pStAR}$, was transfected into HHUA cells without the addition of 22R-hydroxycholesterol to the culture medium (Fig. 5A). Although the production of pregnenolone did not significantly increase with F2 transfection, pStAR transfection increased the progesterone production in HOUA-1 cells. When F2 or pStAR was transfected into HOUA-1 cells, the production of progesterone was significantly increased with the addition of 22R-hydroxycholesterol to the culture medium (Fig. 5B). The production of progesterone in Hep G2 cells was significantly increased with the addition of 22R-hydroxycholesterol to the culture medium when F2, pStAR, or pCDAX was transfected (Fig. 5C). To evaluate progesterone accumulation in endometrial carcinoma cells, we assayed pregnenolone and progesterone in culture media after various periods of culture. In HHUA cells, the level of pregnenolone had increased at $24 \mathrm{~h}$ of culture and then decreased, whereas the level of progesterone had decreased at $24 \mathrm{~h}$ of culture, increased at $36 \mathrm{~h}$ and then gradually decreased again (Fig. 5D). Unlike the situation in HHUA cells, the level of pregnenolone in HOUA-1 cells had decreased at $48 \mathrm{~h}$ of culture and then increased. Progesterone accumulation was observed with time-dependent increases in HOUA-1 cells (Fig. 5E).

\section{Pregnenolone metabolism in endometrial carcinoma cells}

To further examine the metabolism of pregnenolone, we performed steroid metabolism assays. The production levels of $17 \alpha$-hydroxycholesterol (17 OHP4), androstenedione and progesterone (P4) in HHUA cells increased from $12 \mathrm{~h}$ and peaked at $24 \mathrm{~h}$ after the addition of $\left[{ }^{3} \mathrm{H}\right]-\mathrm{P} 5$ to the culture medium. The production of 17 OHP4 was increased much more than that of $\mathrm{P} 4$. The production levels of all of these steroids began to decrease at $36 \mathrm{~h}$ after the addition of $\left[{ }^{3} \mathrm{H}\right]-\mathrm{P} 5$ to the culture medium (Fig. 6A). In HOUA-1 cells, the production of $\mathrm{P} 4,17$ OHP4 and androstenedione gradually increased from $12 \mathrm{~h}$ and the production of $\mathrm{P} 4$ rapidly increased from $24 \mathrm{~h}$ after the addition of $\left.{ }^{3} \mathrm{H}\right]-\mathrm{P} 5$ to the culture medium. Unlike the situation in HHUA cells, the production of progesterone did not decrease after $36 \mathrm{~h}$ in HOUA-1 cells. The production levels of $17 \mathrm{OHP} 4$ and androstenedione increased with the progress of time and peaked between 36 and $48 \mathrm{~h}$ (Fig. 6B). In Hep G2 cells, the production levels of P4, 17 OHP4 and androstenedione increased from $12 \mathrm{~h}$, peaked at $24 \mathrm{~h}$, and then decreased. The production of $\mathrm{P} 4$ increased more than that of $17 \mathrm{OHP} 4$ and androstenedione (Fig. 6C). 
(a)

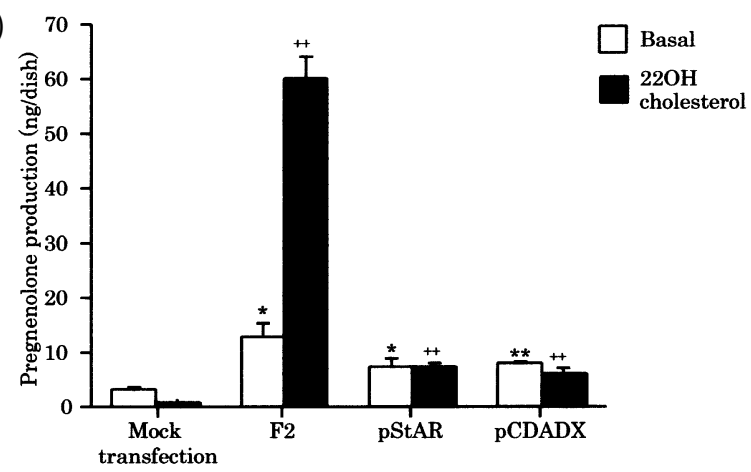

(C)

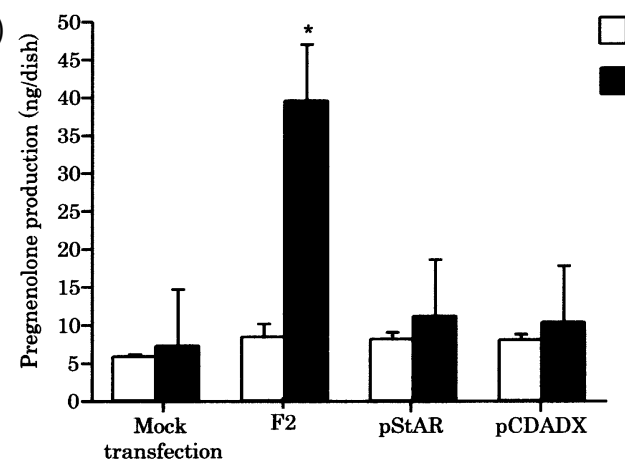

(e)

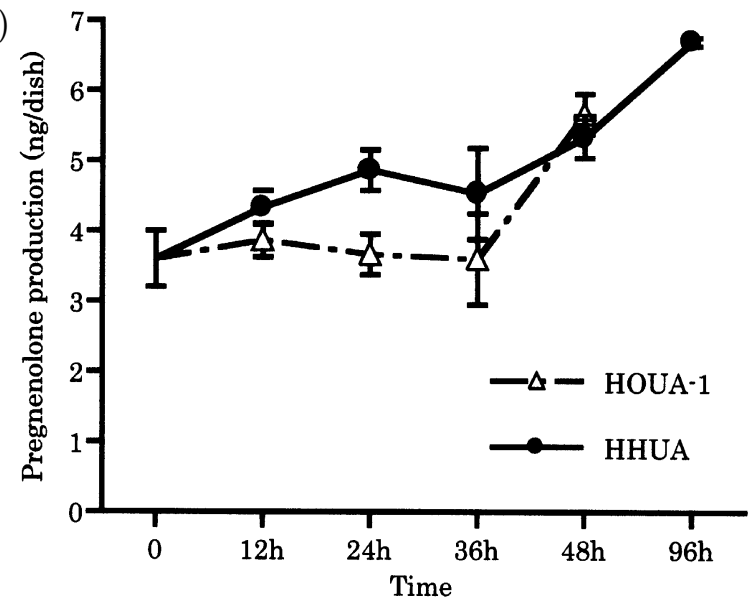

(b)

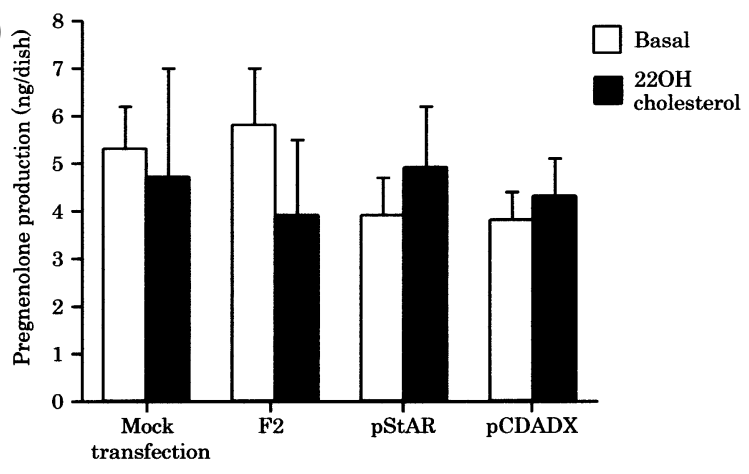

$(d)$

Basal

$22 \mathrm{OH}$

cholesterol
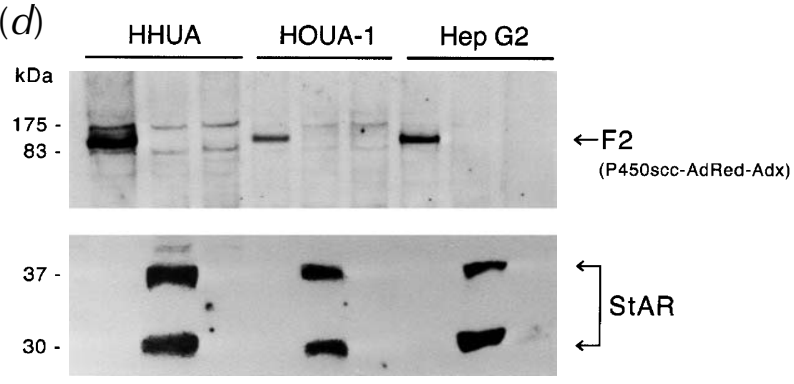

$\begin{array}{rllllllllll}\mathrm{F} 2 & + & - & - & + & - & - & + & - & - \\ \mathrm{pStAR} & - & + & - & - & + & - & - & + & -\end{array}$

Figure 3 Production of steroid hormones in endometrial carcinoma cells. The amount of pregnenolone in the culture medium was measured using RIA. Cells were cultured in $3.5 \mathrm{~cm}$ culture dishes that each contained $2 \mathrm{ml}$ culture medium. The F2 fusion SCC and ADX system, StAR expression vector (pStAR) and ADX expression vector (pCDADX) were transfected into (a) HHUA cells, (b) HOUA-1

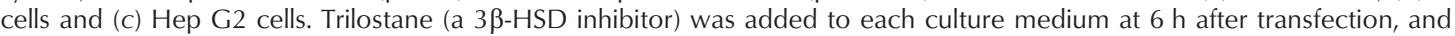
$22 \mathrm{R}$-hydroxycholesterol $(22 \mathrm{OH}$ cholesterol) was added to some dishes $24 \mathrm{~h}$ after transfection. At $48 \mathrm{~h}$ after transfection, the amount of pregnenolone in the medium was measured. The results are presented as means \pm S.E. from three separate experiments.

* Significant difference for basal pregnenolone compared with mock transfection, significant difference for pregnenolone with 22R-hydroxycholesterol compared with mock transfection: ${ }^{*}+P<0 \cdot 05,{ }^{*},{ }^{++} P<0 \cdot 01$. (d) Ten micrograms protein extract were electrophoresed in $12.5 \%$ polyacrylamide gel in the presence of $2 \%$ SDS for immunodetection with rabbit human anti-StAR serum (lower panel) or anti-P450 scc serum (upper panel). (e) Production of pregnenolone was assayed in HHUA and HOUA-1 endometrial carcinoma cells. Cells were cultured to about $60 \%$ confluence in $35 \mathrm{~mm}$ culture dishes. The cells were incubated with $20 \mu \mathrm{M}$ trilostane for the times indicated, and then immunoassay for pregnenolone was performed. The results are presented as means \pm S.E. from three separate experiments. 

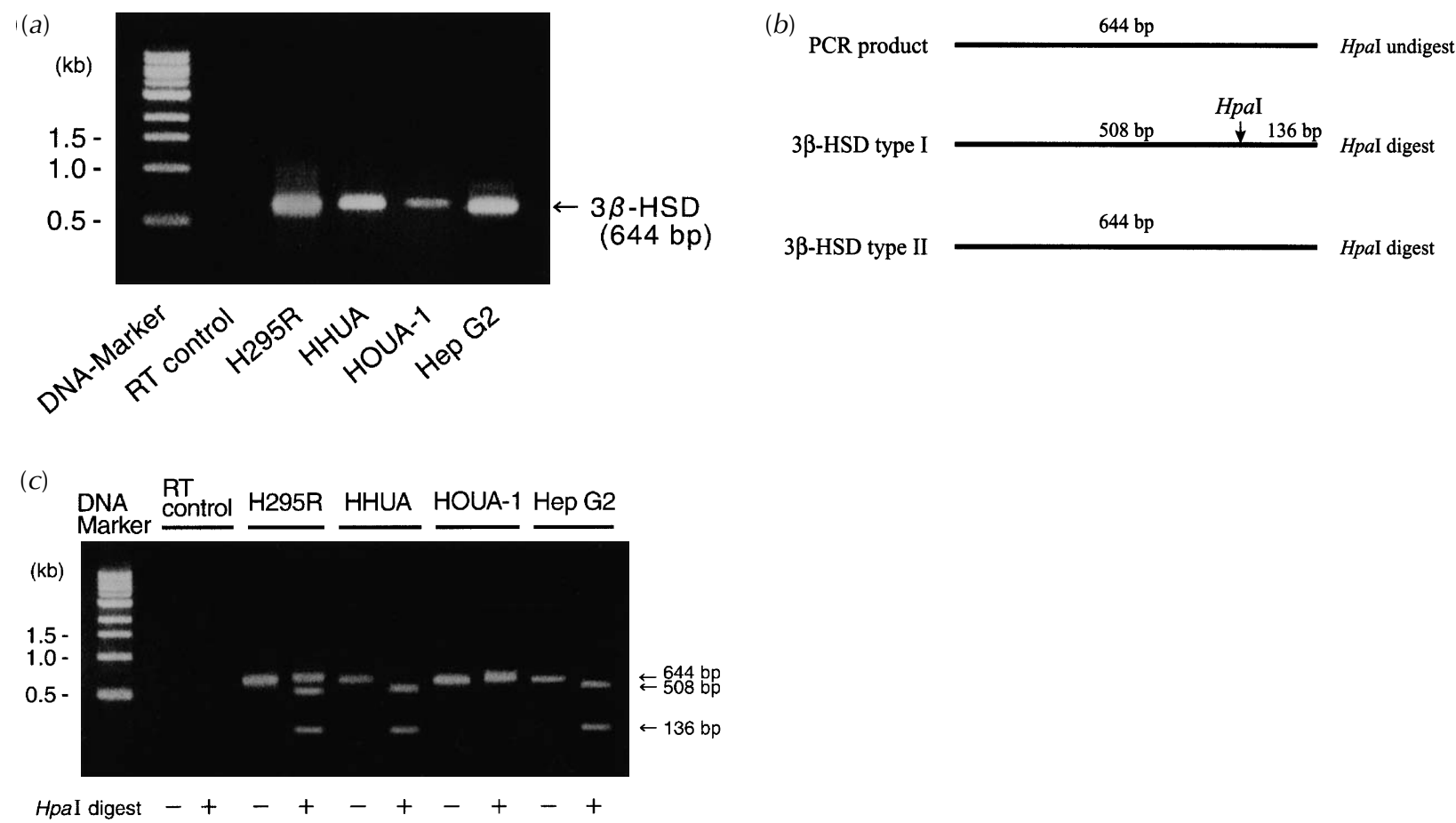

Figure $43 \beta$-HSD expression in endometrial carcinoma cells. (a) RT-PCR was performed using mRNA extracted from HHUA, HOUA-1,

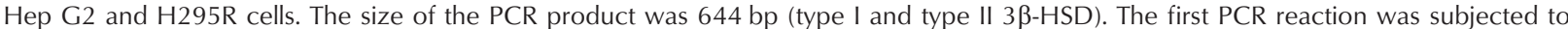
35 cycles and then to 20 cycles. (b) The Hpal restriction site is present in the type I 3 $\beta$-HSD gene. Digestion of type I 3 $\beta$-HSD (644 bp) produced fragments of $588 \mathrm{bp}$ and $136 \mathrm{bp}$. PCR products of type II 33-HSD were not digested with Hpal. (c) One-fifth of the PCR products were digested with Hpal restriction enzyme.

\section{Discussion}

Locally produced steroid hormones play important roles in tissues even if their amounts are small. Steroid hormones that act as modulators of the signal transducer of synapse are synthesized in tissues of the central nervous system (CNS) by conversion of cholesterol (Baulieu 1997). RT-PCR analysis has shown that the StAR gene is co-expressed with P450 scc and 3 $\beta$-HSD in the CNS (Furukawa et al. 1998). As in CNS tissues, the StAR gene was found to be present together with $\mathrm{P} 450 \mathrm{scc}$ and P45017 $\alpha$ in HHUA and HOUA-1 endometrial carcinoma cells. HHUA and HOUA-1 cells have enzymes for synthesizing androstenedione from cholesterol via pregnenolone, progesterone and $17 \alpha$-hydroxyprogesterone. In our study, expression of the aromatase gene was not detected by RT-PCR analysis, although the aromatase gene has been shown to be expressed in stromal cells in endometrial carcinoma tissues (Watanabe et al. 1995, Sasano et al. 1996). In cancerous tissues of patients with endometrial carcinoma, it seems that androstenedione is converted into estradiol.

The fusion protein F2 is composed of the human P450 scc system (Harikrishna et al. 1993). Transfection of the F2 system resulted in increases in pregnenolone production in
HHUA cells and Hep G2 cells but not in HOUA-1 cells. The amount of pregnenolone could only be measured by StAR or the F2 system gene overexpression in HHUA cells, suggesting that the expression levels of StAR protein and P450 scc enzyme in endometrial carcinoma cells are low and that they do not contribute to sufficient production of steroid hormones for detection of steroid hormones in the serum of patients. The production of pregnenolone was not increased by F2 or pStAR transfection in HOUA-1 cells. Pregnenolone may be transformed into other steroidal derivatives or bind uncharacterized receptors, including pregnane $\mathrm{X}$ receptor (Lehmann et al. 1998), to utilize them in HOUA-1 cells.

It is possible to measure the amount of pregnenolone in HHUA cells by adding trilostane, a $3 \beta-H S D$ inhibitor, to a culture medium of the cells (Artemenko et al. 2001). Although pregnenolone was not detected in HOUA-1 cells even when trilostane was added to the culture medium, progesterone was detected without the addition of trilostane. Human type I $3 \beta-H S D$ is expressed in syncytial trophoblasts at high levels, and in sebaceous glands and breast and prostatic cancer cells, while type II $3 \beta-H S D$ is almost exclusively expressed in the adrenal cortex and gonads (Lorence et al. 1990). RT-PCR analysis showed that HHUA cells have a type I $3 \beta-H S D$ and that 
(a)

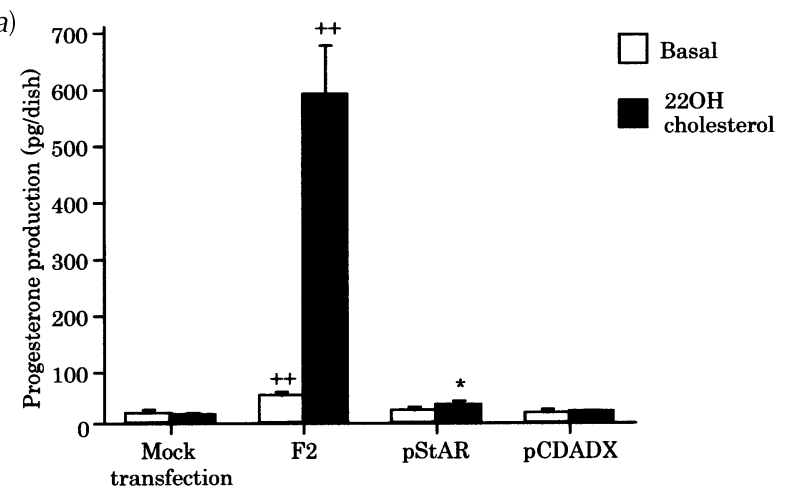

(c)

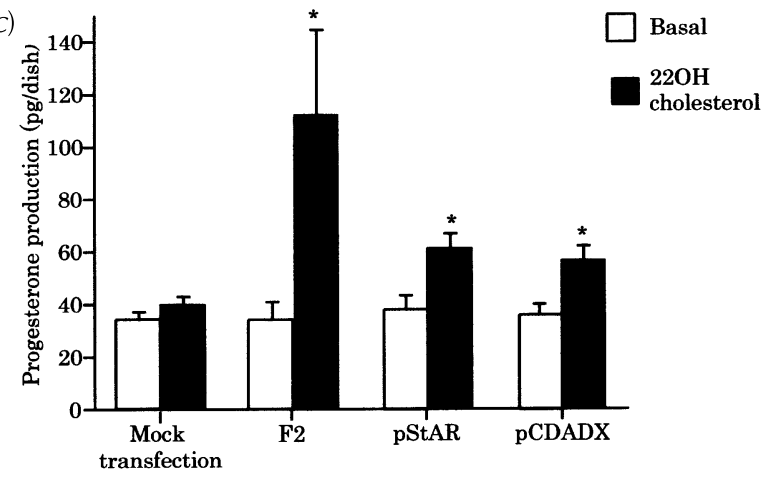

(e)

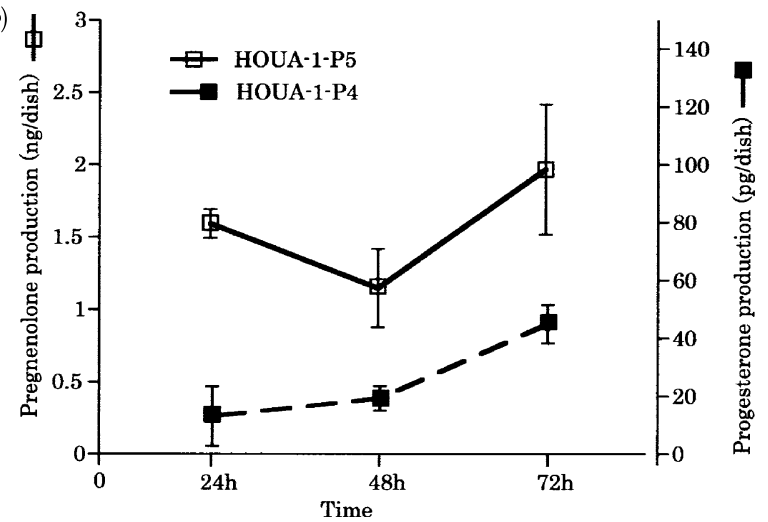

(b)

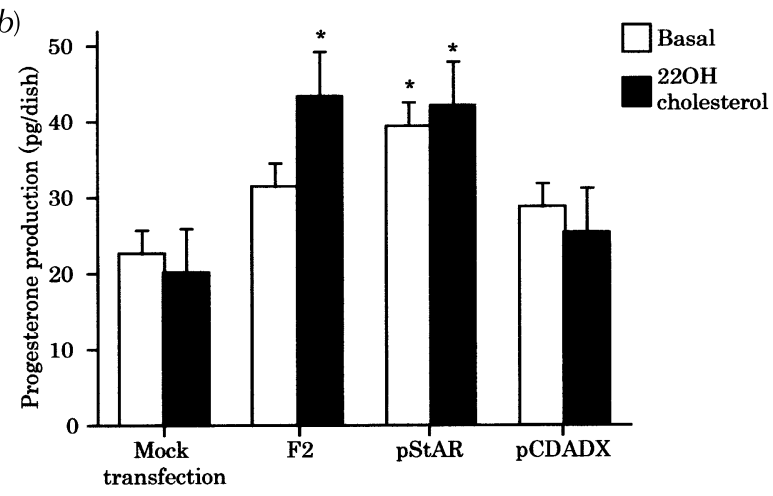

(d)

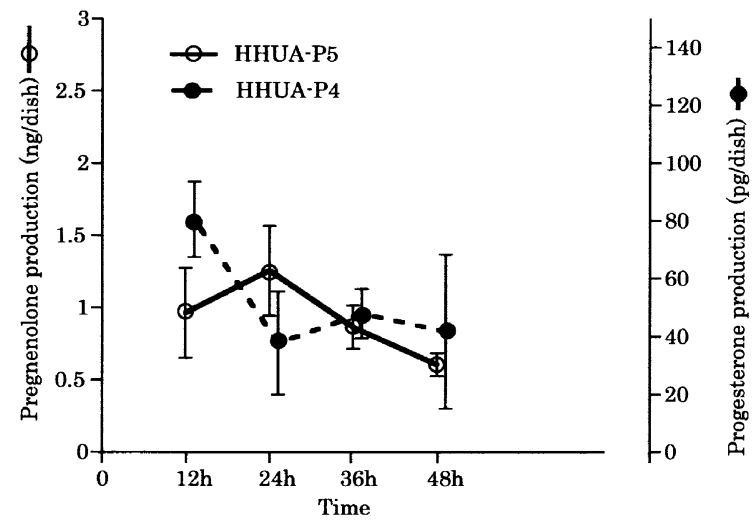

Figure 5 Production of progesterone in endometrial carcinoma cells. The amount of progesterone in the culture medium was measured using ElA. Cells were cultured in $3.5 \mathrm{~cm}$ culture dishes that each contained $2 \mathrm{ml}$ culture medium. F2, pStAR and pCDADX were transfected into (a) HHUA cells, (b) HOUA-1 cells and (c) Hep G2 cells. At $24 \mathrm{~h}$ after transfection, 22R-hydroxycholesterol (22OH cholesterol) was added to some dishes. At $48 \mathrm{~h}$ after transfection, the amount of progesterone in the medium was measured. The results are presented as means \pm S.E. from three separate experiments. *Significant difference for basal pregnenolone compared with mock transfection, ${ }^{+}$significant difference for pregnenolone with $22 \mathrm{R}$-hydroxycholesterol: ${ }^{*}{ }^{+} P<0 \cdot 05,{ }^{* *,+} P<0 \cdot 01$ (d and e) Production of pregnenolone (open symbols) and progesterone (solid symbols) was assayed in (d) HHUA and (e HOUA-1 endometrial carcinoma cells. Cells were cultured to about $60 \%$ confluence in $35 \mathrm{~mm}$ culture dishes. The culture medium was collected at various times after medium change. The results are presented as means \pm S.E. from three separate experiments.

HOUA-1 cells have a type II $3 \beta-H S D$ that converts pregnenolone into progesterone, and results of steroid assays showed that HHUA and HOUA-1 cells convert pregnenolone into progesterone. An interesting finding is that the metabolism of progesterone was much more rapid in HHUA cells than in HOUA-1 cells. HHUA cells have both ER and PR, but HOUA-1 cells do not (Ishiwata et al. 1984). It is possible that HHUA-1 cells utilize intracellular progesterone and thus do not release progesterone into the culture medium. The good prognosis 
(a)

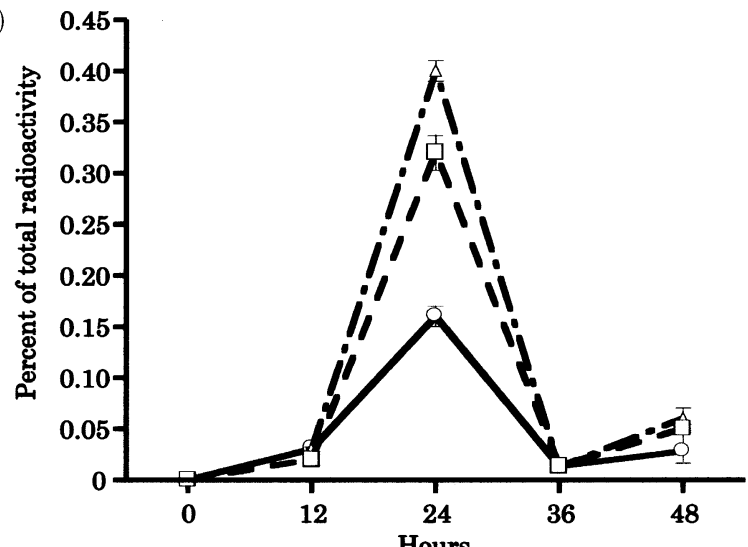

(b)

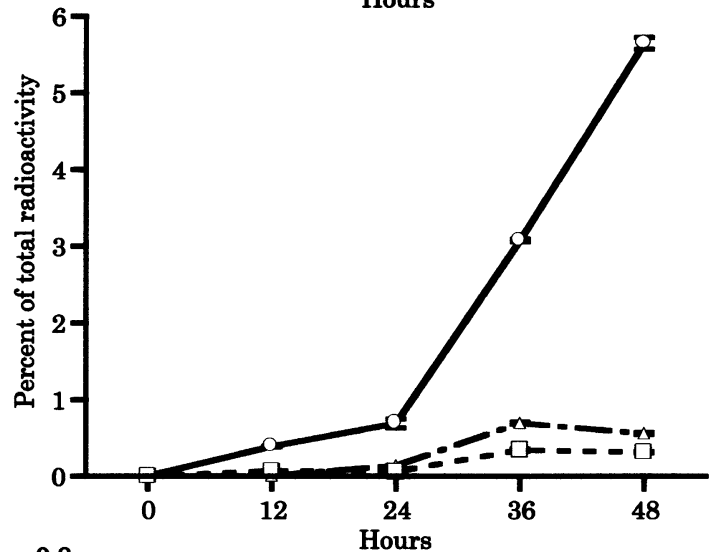

(c)

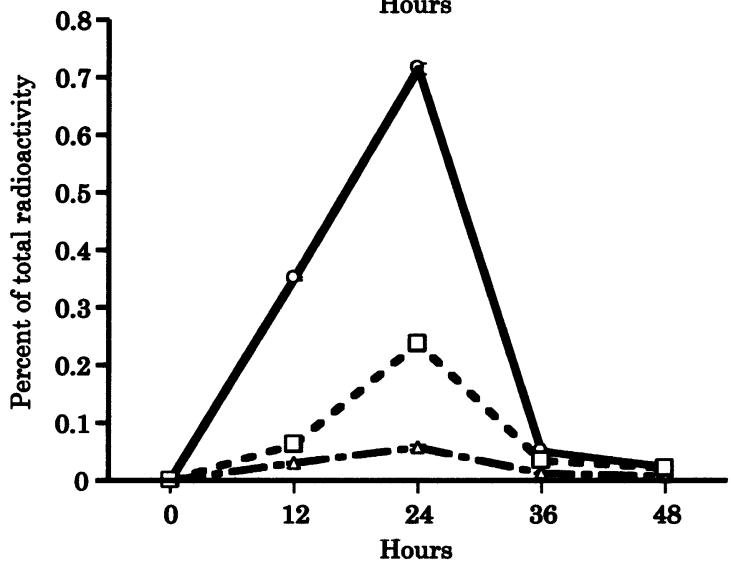

Figure 6 Pregnenolone metabolism in endometrial carcinoma cells. (a) HHUA cells, (b) HOUA-1 cells and (c) Hep G2 cells were grown until subconfluence, and then $2.0 \mu \mathrm{M}$ tritiated pregnenolone $\left(\left[{ }^{3} \mathrm{H}\right]-\mathrm{P} 5\right)$ were added to each culture medium. The media were collected at various times, and steroids were extracted from each medium with dichloromethane. Values are the means \pm S.E. of radioactivity, expressed as a percentage of total activity of $\left[{ }^{3} \mathrm{H}\right]-\mathrm{P} 5$, from three separate experiments in which each treatment group contained three replicate cultures. Progesterone: open circles, solid line; $17 \alpha$-hydroxycholesterol: open triangles, dashed/dotted line; androstenedione: open box, dotted line. of highly differentiated endometrial carcinoma may be associated with the utilization of pregnenolone and the regulation of the growth of carcinoma cells.

It is widely known that the development and growth of endometriotic lesions are dependent on estrogen (Dizerega et al. 1980). Although P450 arom is not expressed in normal endometrium, its expression has been detected in endometriotic tissues (Noble et al. 1996, Bulun et al. 2001). Estrogens are secreted from the ovary and from peripheral tissues (adipose and skin). Estrogens are also produced locally in endometriotic tissue itself. Expressions of genes associated with steroid hormone synthesis, i.e. StAR, P450 scc and P45017 $\alpha$ genes have recently been detected not only in the normal endometrium but also in endometriotic tissues (Tsai et al. 2001). It is possible that endometriotic tissues not only convert circulating androstenedione in plasma but also produce de novo steroid hormones from cholesterol (Tsai et al. 2001). Locally produced steroid hormones may play roles in estrogendependent growth of endometriotic lesions with an autocrine or paracrine action.

The present study has shown that endometrial carcinoma cells express steroidogenic enzymes, synthesize steroid hormones from cholesterol, and convert pregnenolone into androstenedione. Further study is needed to determine the ability of cells in endometrial carcinoma tissues from patients to produce steroid hormones and to clarify the relationship between production levels of steroid hormones and prognosis of endometrial carcinoma patients.

\section{Funding}

This work was supported in part by a Grant-in-Aid from the Ministry of Education, Science and Culture, Japan. The authors declare that they have no competing financial interests.

\section{References}

Artemenko IP, Zhao D, Hales DB, Hales KH \& Jefcoate CR 2001 Mitochondrial processing of newly synthesized steroidogenic acute regulatory protein (StAR), but not total StAR, mediates cholesterol transfer to cytochrome $\mathrm{P} 450$ side chain cleavage enzyme in adrenal cells. Journal of Biological Chemistry 276 46583-46596.

Baulieu EE 1997 Neurosteroids: of the nervous system, by the nervous system, for the nervous system. Recent Progress in Hormone Research 52 1-32.

Bulun SE, Yang S, Fang Z, Gurates B, Tamura M, Zhou J \& Sebastian S 2001 Role of aromatase in endometrial disease. Journal of Steroid Biochemistry and Molecular Biology 79 19-25.

Dizerega GS, Barber DL \& Hodgen GD 1980 Endometriosis: role of ovarian steroids in initiation, maintenance, and suppression. Fertility and Sterility 33 649-653.

Furukawa A, Miyatake A, Ohnishi T \& Ichikawa Y 1998 Steroidogenic acute regulatory protein (StAR) transcripts constitutively expressed in the adult rat central nervous system: 
colocalization of StAR, cytochrome P-450 SCC (CYP XIA1), and 3 beta-hydroxysteroid dehydrogenase in the rat brain. Journal of Neurochemistry $712231-2238$.

Harikrishna JA, Black SM, Szklarz GD \& Miller WL 1993 Construction and function of fusion enzymes of the human cytochrome P450 scc system. DNA and Cell Biology 12 371-379.

Ishiwata I, Ishiwata C, Soma M, Arai J \& Ishikawa H 1984 Establishment of human endometrial adenocarcinoma cell line containing estradiol-17 beta and progesterone receptors. Gynecologic Oncology 17 281-290.

Kayes-Wandover KM \& White PC 2000 Steroidogenic enzyme gene expression in the human heart. Journal of Clinical Endocrinology and Metabolism 85 2519-2525.

Kelley RM \& Baker WH 1961 Progestational agents in the treatment of carcinoma of the endometrium. New England Journal of Medicine $264216-222$.

Kelsey JL, LiVolsi VA, Holford TR, Fischer DB, Mostow ED, Schwartz PE, O'Connor T \& White C 1982 A case-control study of cancer of the endometrium. American Journal of Epidemiology 116 333-342.

Le Goascogne C, Robel P, Gouezou M, Sananes N, Baulieu EE \& Waterman M 1987 Neurosteroids: cytochrome P-450 scc in rat brain. Science 237 1212-1215.

Lehmann JM, McKee DD, Watson MA, Willson TM, Moore JT \& Kliewer SA 1998 The human orphan nuclear receptor PXR is activated by compounds that regulate CYP3A4 gene expression and cause drug interactions. Journal of Clinical Investigation 102 $1016-1023$.

Lin D, Sugawara T, Strauss JF 3rd, Clark BJ, Stocco DM, Saenger P, Rogol A \& Miller WL 1995 Role of steroidogenic acute regulatory protein in adrenal and gonadal steroidogenesis. Science $\mathbf{2 6 7}$ 1828-1831.

Lorence MC, Murry BA, Trant JM \& Mason JI 1990 Human 3 beta-hydroxysteroid dehydrogenase/delta 5 -delta 4 isomerase from placenta: expression in nonsteroidogenic cells of a protein that catalyzes the dehydrogenation/isomerization of C21 and C19 steroids. Endocrinology 126 2493-2498.

McCarty KS Jr, Barton TK, Fetter BF, Creasman WT \& McCarty KS Sr 1979 Correlation of estrogen and progesterone receptors with histologic differentiation in endometrial adenocarcinoma. American Journal of Pathology 96 171-183.

Matteson KJ, Chung BC, Urdea MS \& Miller WL 1986a Study of cholesterol side-chain cleavage (20,22 desmolase) deficiency causing congenital lipoid adrenal hyperplasia using bovine-sequence P450 scc oligodeoxyribonucleotide probes. Endocrinology 118 1296-1305.

Matteson KJ, Picado-Leonard J, Chung BC, Mohandas TK \& Miller WL 1986 b Assignment of the gene for adrenal P450c17 (steroid 17 alpha-hydroxylase/17,20 lyase) to human chromosome 10 . Journal of Clinical Endocrinology and Metabolism 63 789-791.

Nelson VL, Legro RS, Strauss JF 3rd \& McAllister JM 1999 Augmented androgen production is a stable steroidogenic phenotype of propagated theca cells from polycystic ovaries. Journal of Molecular Endocrinology 13 946-957.

Noble LS, Simpson ER, Johns A \& Bulun SE 1996 Aromatase expression in endometriosis. Journal of Clinical Endocrinology and Metabolism 81 174-179.

Potts GO, Creange JE, Hardomg HR \& Schane HP 1978 Trilostane, an orally active inhibitor of steroid biosynthesis. Steroids $\mathbf{3 2}$ 257-267.
Rheaume E, Lachance Y, Zhao HF, Breton N, Dumont M, de Launoit Y, Trudel C, Luu-The V, Simard J \& Labrie F 1991 Structure and expression of a new complementary DNA encoding the almost exclusive 3 beta-hydroxysteroid dehydrogenase/delta 5-delta 4-isomerase in human adrenals and gonads. Journal of Molecular Endocrinology 5 1147-1157.

Rheaume E, Simard J, Morel Y, Mebarki F, Zachmann M, Forest MG, New MI \& Labrie F 1992 Congenital adrenal hyperplasia due to point mutations in the type II 3 beta-hydroxysteroid dehydrogenase gene. Nature Genetics 1 239-245.

Runowicz CD, Nuchtern LM, Braunstein JD \& Jones JG 1990 Heterogeneity in hormone receptor status in primary and metastatic endometrial cancer. Gynecologic Oncology 38 437-441.

Sasano H, Kaga K, Sato S, Yajima A, Nagura H \& Harada N 1996 Aromatase cytochrome P450 gene expression in endometrial carcinoma. British Journal of Cancer 74 1541-1544.

Simpson ER, Evans CT, Corbin CJ, Powell FE, Ledesma DB \& Mendelson CR 1987 Sequencing of cDNA inserts encoding aromatase cytochrome P-450 (P-450 AROM). Molecular and Cellular Endocrinology 52 267-272.

Spona J, Ulm R, Bieglmayer C \& Husslein P 1979 Hormone serum levels and hormone receptor contents of endometria in women with normal menstrual cycles and patients bearing endometrial carcinoma. Gynecologic and Obstetric Investigation 10 71-80.

Strauss JF 3rd, Kallen CB, Christenson LK, Watari H, Devoto L, Arakane F, Kiriakidou M \& Sugawara T 1999 The steroidogenic acute regulatory protein (StAR): a window into the complexities of intracellular cholesterol trafficking. Recent Progress in Hormone Research 54 369-394.

Sugawara T, Holt JA, Driscoll D, Strauss JF 3rd, Lin D, Miller WL, Patterson D, Clancy KP, Hart IM, Clark BJ et al. 1995 Human steroidogenic acute regulatory protein: functional activity in COS-1 cells, tissue-specific expression, and mapping of the structural gene to $8 \mathrm{p} 11.2$ and a pseudogene to chromosome 13. PNAS 92 $4778-4782$

Takeda Y, Miyamori I, Yoneda T, Hatakeyama H, Inaba S, Furukawa K, Mabuchi H \& Takeda R 1996 Regulation of aldosterone synthase in human vascular endothelial cells by angiotensin II and adrenocorticotropin. Journal of Clinical Endocrinology and Metabolism 81 2797-2800.

Toaff ME, Schleyer H \& Strauss JF 3rd 1982 Metabolism of 25-hydroxycholesterol by rat luteal mitochondria and dispersed cells. Endocrinology 111 1785-1790.

Tsai SJ, Wu MH, Lin CC, Sun HS \& Chen HM 2001 Regulation of steroidogenic acute regulatory protein expression and progesterone production in endometriotic stromal cells. Journal of Clinical Endocrinology and Metabolism 86 5765-5773.

Watanabe K, Sasano H, Harada N, Ozaki M, Niikura H, Sato S \& Yajima A 1995 Aromatase in human endometrial carcinoma and hyperplasia. Immunohistochemical, in situ hybridization, and biochemical studies. American Journal of Pathology 146 491-500.

Received in final form 27 August 2003

Accepted 5 September 2003

Made available online as an

Accepted Preprint 15 September 2003 